\title{
Recerca geològica i mineralògica per la comarca del Pallars Sobirà: des de Sort i la Bàstida de Sort a Rialp, Montenartró, Romadriu i a Sant Joan de l'Erm Nou
}

Josep Maria Mata-Perelló

Joaquim Sanz Balagué

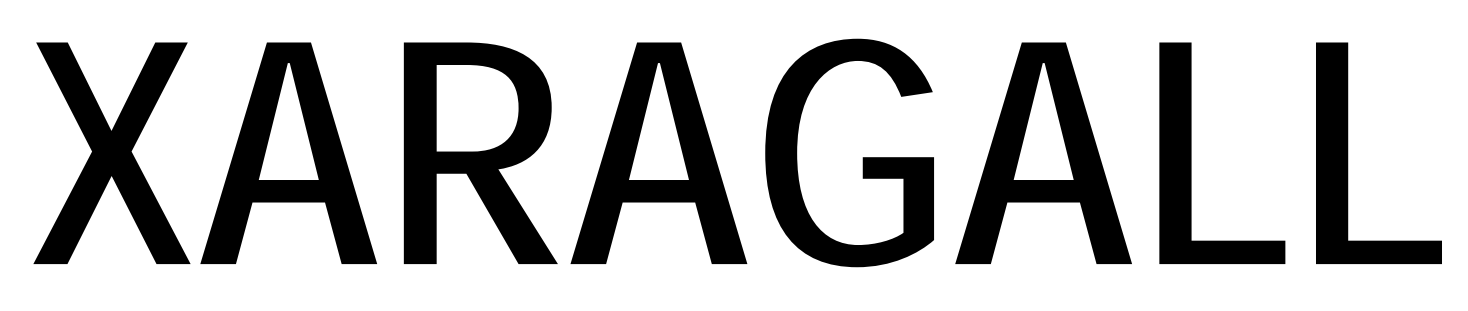

REVISTA DE CIÈNCIES DE LA CATALUNYA CENTRAL n. 10

OCTUBRE 2014 


\title{
RECERCA GEOLÒGICA I MINERALÒGICA PER LA COMARCA DEL PALLARS SOBIRÀ: DES DE SORT I LA BÀSTIDA DE SORT A RIALP, MONTENARTRÓ, ROMADRIU I A SANT JOAN DE L’ERM NOU
}

\author{
Josep Maria Mata-Perelló \\ Museu de geologia Valentí Masachs, Escola Politècnica Superior d'Enginyeria de Manresa \\ (EPSEM), Universitat Politècnica de Catalunya · BarcelonaTech (UPC), 08272 Manresa, Spain
}

\section{Joaquim Sanz Balagué}

Departament d'Enginyeria Minera i Recursos Naturals (EMRN), Escola Politècnica Superior d'Enginyeria de Manresa (EPSEM), Universitat Politècnica de Catalunya - BarcelonaTech (UPC), 08272 Manresa, Spain

Paraules clau: Sistema Pirinenc, Unitat del Mantell de les Nogueres, Materials Paleozoics, Patrimoni miner

\section{Resum}

Itinerari realitzat el 20 d'octubre de 2013. En aquesta ocasió, la totalitat del recorregut de I'itinerari discorrerà pel Sistema Pirinenc. Així, en la seva primera part, entre Sort i els Hostalets de la Bastida (prop de Rialp de Noguera) ho farà per la Unitat del Mantell de les Nogueres (la qual forma part de les tradicionalment anomenades Serres Exteriors Prepirinenques). En aquest tram, trobarem fonamentalment afloraments dels materials mesozoics del triàsic Superior, del Keuper.

Després, entre Rialp de Noguera i les immediacions de Sant Joan de l'Erm (al final del recorregut), el recorregut de l'itinerari discorrerà per la Zona Axial Pirinenca (en concret per la denominada Unitat dels Apilaments de la Zona Axial). En aquest tram del recorregut, trobarem fonamentalment afloraments dels materials paleozoics, de I'Ordovicià, del Silurià, del Devonià i del Carbonífer.

Per altra banda, el recorregut de l'itinerari discorrerà íntegrament per una sola comarca, concretament per la del Pallars Sobirà (encara que finalitzarà prop de la comarca de I'Alt Urgell), situada dintre de la Regió de Tremp (o de Tremp-Seu d'Urgell). 


\section{Objectius fonamentals}

Es centraran en els aspectes geològics, geomorfològics i mineralògics que apuntarem a continuació:

1. Estudi de les estructures més meridionals de la Unitat del Mantell de les Nogueres. El recorregut de l'itinerari transitarà per aquesta unitat entre la població de Sort i els Hostalets de la Bastida.

2. Observació i descripció dels materials mesozoics (els quals pertanyen al Triàsic, exclusivament), que constitueixen la Unitat del Mantell de les Nogueres, per aquests indrets del recorregut. En alguns llocs, els podem trobar parcialment recoberts per materials detrítics oligocènics, de caràcter postorogènic.

3. Observació de l'estructura del sector corresponent als Apilaments Antiformes de la Zona Axial Pirinenca, per entre la qual discorrerà la segona part del recorregut de l'itinerari. Aquest recorregut s'efectuarà entre la població de Rialb de Noguera i Sant Joan de I’Erm Vell (on finalitzarà el recorregut).

4. Observació dels materials paleozoics de la denominada Unitat dels Apilaments de la Zona Axial Pirinenca. Aquests materials es distribueixen fonamentalment pels terrenys paleozoics. els quals van des del Cambro-Ordovicià fins al Carbonífer. Nosaltres anirem trobant aquests materials al llarg de tot el recorregut esmentat a l'apartat anterior.

5. Observació, si s'escau de les relacions existents entre la Unitat del Mantell de les Nogueres i la Unitat dels Apilaments de la Zona Axial Pirinenca

6. Reconeixement de diverses mineralitzacions situades al llarg del recorregut del present itinerari, com les següents (d'acord amb el recorregut de l’itinerari):

6A) de les mineralitzacions d'EPIDOTA, relacionades amb roques ofitíques. Es troben a la Bàstida de Sort, dintre de la Unitat del Mantell de les Nogueres.

6B) de les mineralitzacions estaminíferes filonianes, associades a fractures. Nosaltres, si es dona el cas, les trobarem al terme de Montenartró (Pallars Sobirà), dintre dels Apilaments Antiformes de la Zona Axial Pirinenca.

7. Observació de les explotacions mineres relacionades amb les mineralitzacions esmentades a l'apartat anterior.

8. Observació, si s'escau, de les repercussions sobre el Medi Natural (i sobre el Medi Ambient) provocades per les explotacions mineres i també pels vials de comunicació.

9. Observació dels diferents indrets relacionats amb el Patrimoni Miner i Geològic, que anirem trobant al llarg del present itinerari. 


\section{Antecedents}

Pel que fa al recorregut d'aquest itinerari, en la seva primera part (entre Sort i Rialb de Noguera), hi ha diversos antecedents nostres, publicat els darrers anys. Entre ells, farem esment dels següents: Mata-Perelló (1995a, 1995b, 1996d, 1998 i 2002, 2009a, 2009b i 2012). També, en farem d'un altre treball en part nostre: Mata-Perelló i Sanz (1993). Pel que fa al recorregut entre Rialp, Montenartró, Romadriu i Sant Joan de l'Erm Vell, sols coneixem un antecedent nostre: Mata-Perelló (2009c).

Pel que fa a les mineralitzacions que veurem en aquest itinerari, cal dir que també ja estat prèviament descrites per nosaltres en Mata-Perelló (1991). En aquest treball es fa referència a les mineralitzacions catalanes en general, parlant-se també de les situades al llarg d'aquest itinerari.

I pel que fa a l'estructura geològica, ens remetem al treball de RIBA et altri (1976), i al de Guimerà et altri (1992). En ambdós, es fa referència a l'estructura geològica dels Països Catalans. Per d'altra banda, també ens remetem a SGC (1990).

Finalment, cal dir que tots aquests treballs, es trobaran relacionats, per estricte ordre alfabètic, dintre de l'apartat dedicat a les REFERĖNCIES BIBLIOGRÀFIQUES, al qual es remetem, pel que s'escaigui.

\section{Recorregut de l'itinerari}

El recorregut del present itinerari s'iniciarà per les immediacions de Sort, per on s'efectuaran les primeres aturades. Tot seguit, el recorregut es dirigirà cap a la Bastida de Sort (a través la carretera C-13), fent-se una nova aturada en arribar a l'Hostalet. Seguidament el recorregut es dirigirà cap a Rialp de Noguera.

Després de sobrepassar la població., es continuarà cap al Nord, fins trobar el trencall (per la dreta) que es dirigeix cap a les pistes d'esquí de l'Orri i de Port Ainé. En trobar aquest vial, ens caldrà agafar-lo. Així passarem per Roni (deixant per la dreta la carretera cap a les pistes d'esquí). Finalment arribarem a la població de Montenartró. Des d'aquesta darrera població ens caldrà anar cap a Romadriu, per on farem una nova aturada a la Farga de Romadriu.

Després de fer l'aturada anterior, ens caldrà retornar de nou cap a Montenartró, des d'on ens caldrà seguir pel camí que condueix cap a Sant Joan de I'Erm Vell. Abans, però, ens caldrà agafar el trencall que ens durà cap a les antigues Mines d'Antimoni de Montenartró, per on farem una nova aturada.

Finalment, ens caldrà continuar de nou cap a Sant Joan de l'Erm Vell, per on farem la darrera aturada. Tot i així, si s'escau, podem continuar cap a Sant Joan de I'Erm Nou, per on finalitzarem aquest itinerari. 


\section{Advertiments previs}

Com en altres recorreguts de RECERCA GEOLÒGICA I MINERALÒGICA... si es disposa del temps suficient, poden efectuar-se passant per totes les parades i filloles. En cas contrari, recomanem prescindir de les anomenades PARADES - CONDICIONALS.

En aquest itinerari, cal tenir força cura del coneixement sobre l'estat de les pistes de muntanya. Així, cal cercar la convenient informació abans de començar el recorregut. En aquest cas, hi ha alguns trams susceptibles de trobar-se en mal estat de conservació. Aquest pot ser el cas dels camins dels voltants de Romadriu, Montenartró i de Sant Joan de I’Erm Vell.

Per d'altra banda, i com de costum, recomanem tenir el màxim respecte per la natura, tant al llarg d'aquest recorregut, com en qualsevol moment, al marge d'ell.

\section{Descripció de l'itinerari}

En aquest recorregut hem situat, com ja és habitual en tots els itineraris, una sèrie d'ESTACIONS o de PARADES, que anirem veient a continuació. En cada cas, els hi donarem una denominació que podrà correspondre a algun paratge proper. També indicarem el terme municipal i la comarca on es troba.

Per altra banda, en cadascuna de les parades, indicarem entre parèntesi el número del "Mapa Topográfico" (de I'Instituto Grográfico y Catastral de España), a escala 1:50.000, on es troba situada la parada considerada. En aquesta ocasió serà algú dels dos fulls següents: 214 (o de Sort) i 215 (o de la Seu d'Urgell).

Així doncs, la relació de les parades ordenades, que constitueixen aquest itinerari, és la següent

\subsection{Parada 1 - CONDICIONAL. FORN DE GUIX DEL CEMENTIRI, (terme municipal de Sort, comarca del Pallars Sobirà). (Full 214).}

Tot i que el recorregut de l'itinerari el començarem a la població de Sort, ens caldrà fer un petit recorregut per la carretera nacional $\mathrm{N}$ - 260 (coincidint aquí amb la carretera autonòmica C-13). Així, ens caldrà fer un recorregut, cap el Sud, proper als $3 \mathrm{Km}$. Poc abans d'arribar al Cementiri de Sort, caldrà fer una aturada. Aquesta es farà per les immediacions de l'inici de la carretera a Enviny.

En aquest recorregut hem anat trobant els materials que formen part del Mantell de les Nogueres. Així, haurem trobat afloraments dels materials triàsics del Keuper, amb nivells de guixos i d'argiles, fonamentalment

Precisament, en aquest indret hi ha un aflorament dels nivells de guixos triàsics del Keuper, els quals va ésser utilitzats com a matèria prima per a un forn de guix proper. Pel que fa a aquest forn de guix, cal dir que aquest es troba en relatiu bon estat de conservació, tot i que caldria realitzar tasques de manteniment. (fotografia 1 ). 


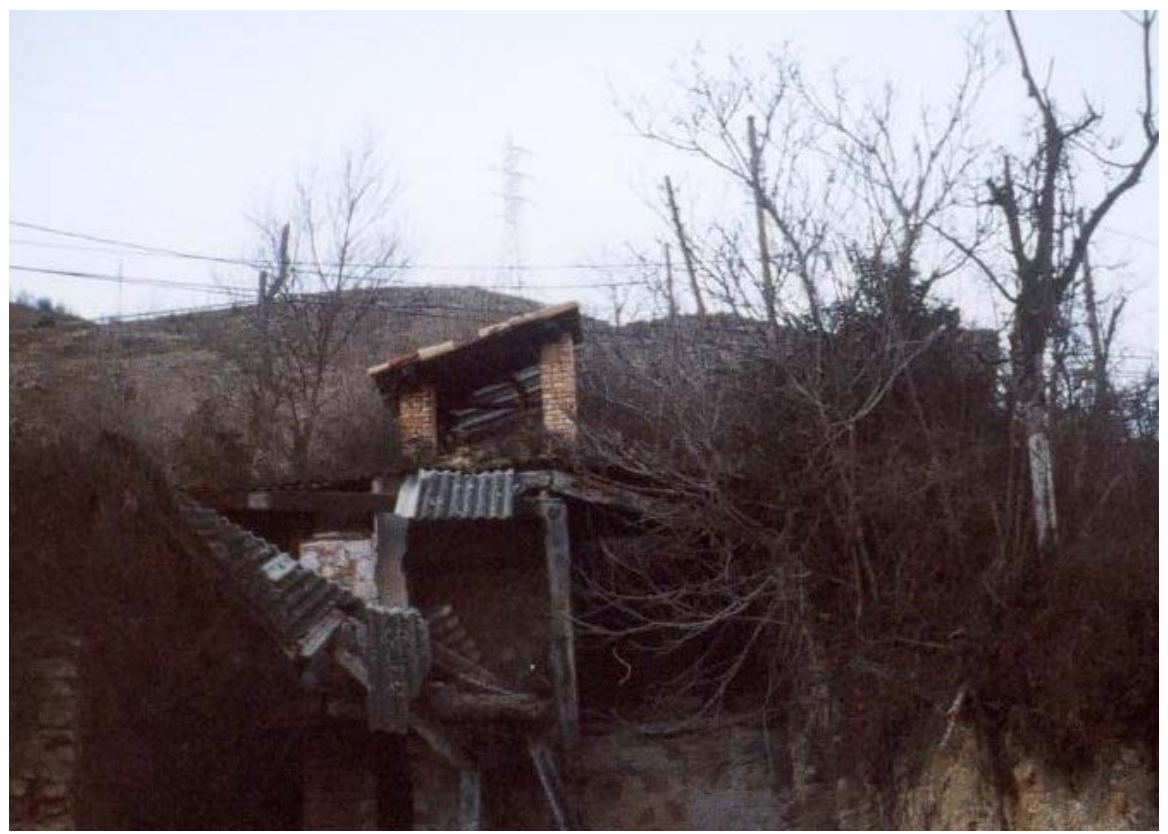

Fotografia 1. Restes del forn de guix del cementiri de Sort. Fotografia del març del 2002

\subsection{Parada 2. FORN DE CALÇ DE SORT, (terme municipal de Sort, comarca del Pallars Sobirà). (Full 214).}

Després de realitzar la parada anterior, cal tornar enrere cap a la població de Sort. Just quasi abans d'arribar-hi, caldrà fer una nova aturada. Així, circularem per la carretera N-260 (que coincideix aquí amb la C-13). A l'entrada de la població, al costat de l'antic forn de calç, farem aquesta aturada.

Cal dir que en aquest recorregut, hem tornat a trobar els afloraments dels materials del Triàsic Superiors, del Keuper. Ara ens trobem situats dintre del Mantell de les Nogueres, per on es troba la població de Sort entre afloraments dels materials triàsics del Keuper, amb nivells de guixos i d'argiles.

Tot i així, pels voltants dels sectors occidentals de Sort es fan palesos els afloraments dels materials carbonatats del Triàsic Mig, del Muschelkalk, situats també dintre del Mantell de les Nogueres, on estem plenament situats.

En canvi, cap els sectors orientals de la població de Sort, es troben afloraments dels materials esquistosos del Cambro-Ordovicià, els quals es situen dintre dels Apilaments de la Zona Axial Pirinenca. Aquests materials es situen plenament a l'esquerra del Noguera Pallaresa (en sentit descendent)

Pel que fa al forn de calç, cal dir que constitueix un bon exemple d'aquests sistemes d'aprofitament dels materials carbonatats, de cara a l'obtenció de calç. En aquest cas s'utilitzaven els afloraments carbonatats del triàsic. També cal dir que no és l'únic forn de calç que hi per aquest indret. (fotografia 2). 


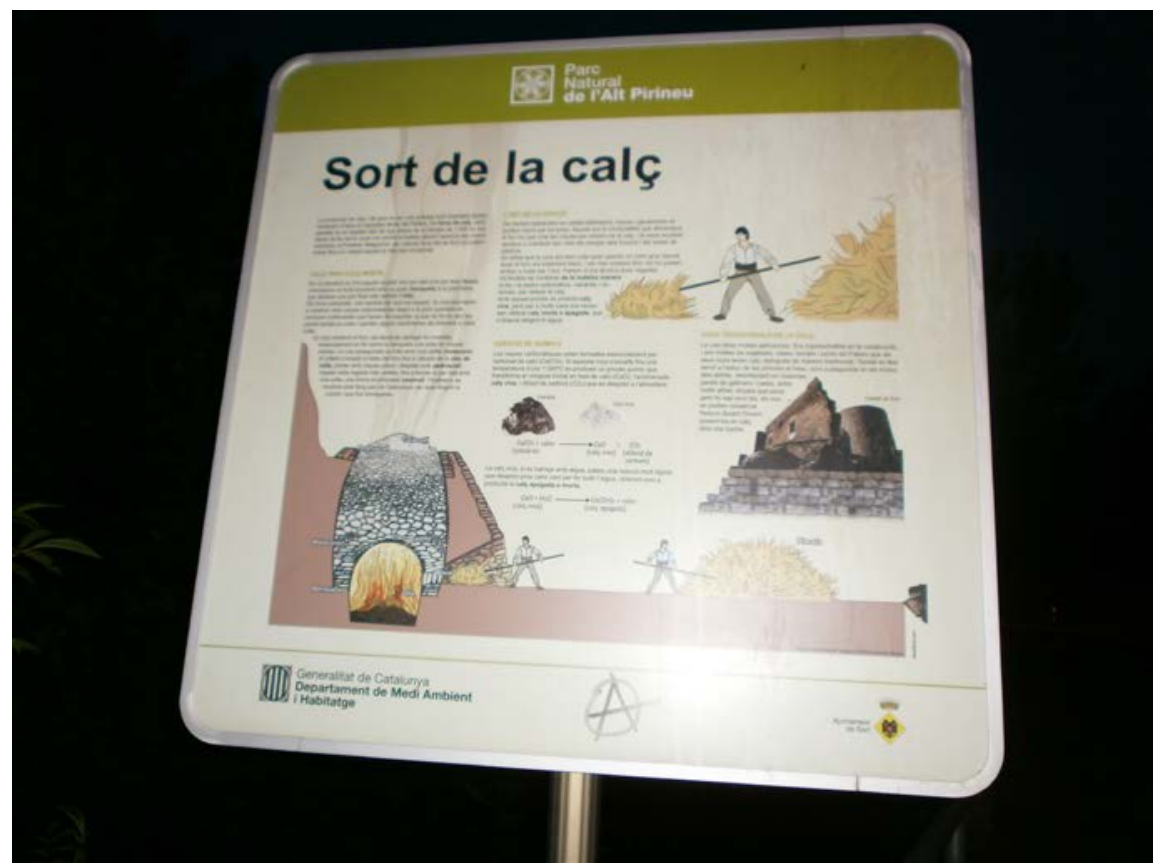

Fotografia 2. Cartell relatiu als treballs del forn de calç de Sort. Octubre del 2002

\subsection{Parada 3. L'HOSTALET, CARRETERA A RIALB DE NOGUERA (la Bàstida de Sort, terme de Sort, comarca del Pallars Sobirà). (Full 214).}

Des de la parada anterior, cal acabar d'arribar a Sort, per tal de continuar per la C-13 (ara ja solament amb aquesta denominació), en direcció cap a Rialp de Noguera, per tal d'anar cap a les immediacions de la Bàstida de Sort. A uns $2 ` 5-3 \mathrm{Km}$ de Sort, es troba al costat esquerre de la carretera i per sota del darrer poble, un interessant aflorament de les ofites del Keuper. Aquest indici, es troba a uns 100 m, aproximadament del llogarret de l'Hostalet. Aquí, és on hem de fer la present aturada.

En aquest breu recorregut, s' han anat tallant els materials triàsics del Keuper. I, precisament en aquest indret de la parada hi afloren els esmentats materials del Keuper, amb nivells de guixos i d'argiles versicolors, i amb afloraments d'ofites. Tots aquests materials formen part del Mantell de la Unitat de les Nogueres.

Tot i així, per l'altra banda del riu es fan palesos els afloraments dels materials de l'Ordovicià (del Cambro - Ordovicià). Aquests materials són fonamentalment esquistos i quarsites, que es situen dintre dels Apilaments Antiformes de la Zona Axial Pirinenca.

Aquí, on som ara, entre els materials ofítics, es troben presents alguns minerals com I'EPIDOTA, molt abundant, i d'un intens color verd. Al respecte, aquesta és una de les localitats més conegudes de Catalunya, per la presència de les epidotes al Keuper. 


\subsection{Parada 4. FARGA DE ROMADRIU, (terme municipal de Castellbó, comarca de l'Alt Urgell). (Full 215).}

Des de la parada anterior, ens caldrà continuar per la carretera $C-13$, anant sempre cap el Nord. Així, travessarem la població de Rialp de Noguera. A la sortida, trobarem per l'esquerra el trencall de Caregue. Més endavant, seguint per I'esmentada carretera autonòmica C - 13, trobarem per la dreta el trencall de la carretera de Montenartró i de les Pistes d'Esquí de Port Ainé. Així, ens caldrà agafar aquesta carretera local. Per ella, aviat passarem pel trencall de Brani. Més endavant en arribar a Roni, trobarem per la dreta el trencall que es dirigeix cap a les Pistes d'Esquí de Port Ainé. Nosaltres haurem de continuar cap a Montenartró. En arribar al poble, ens caldrà continuar cap a Romadriu. Finalment, des d'aquest indret, ens caldrà remuntar el Riu Magdalena i en menys de $1 \mathrm{Km}$ arribarem a l'indret on hi ha les restes de la Farga de Romadriu. Aquí farem una nova aturada, a uns $17 \mathrm{Km}$ de la parada anterior.

En aquest llarg recorregut, inicialment haurem estat circulant entre els materials triàsics del Mantell de les Nogueres. Més endavant, haurem trobat afloraments dels materials paleozoics de I'Ordovicià (i del Cambro - Ordovicià). Aquests afloraments es troben constituïts per esquistos i per quarsites, fonamentalment. Aquests materials, per d'altra banda, es situen dintre dels Apilaments Antiformes de la Zona Axial Pirinenca, on estem ara situats. Així, ara podem veure per arreu, aquests nivells de l'Ordovicià.

En aquest indret, hi ha les restes d'una antiga Farga Catalana, mitjanament conservada. En ella s'utilitzaven les menes de ferro (GOETHITA, fonamentalment, en forma de LIMONITA._molt terrosa) extretes pels voltants d'Arnau, entre altres indrets. Tot i això, creiem que la major part del mineral emprat a la farga, baixava des de les Mines de les Bordes de Conflent, riu avall.

Aquest establiment forma part del nostre Patrimoni Miner i encara es poden veure diversos murs, així com les restes del canalet d'aigua. (fotografies 3, 4, i 5).

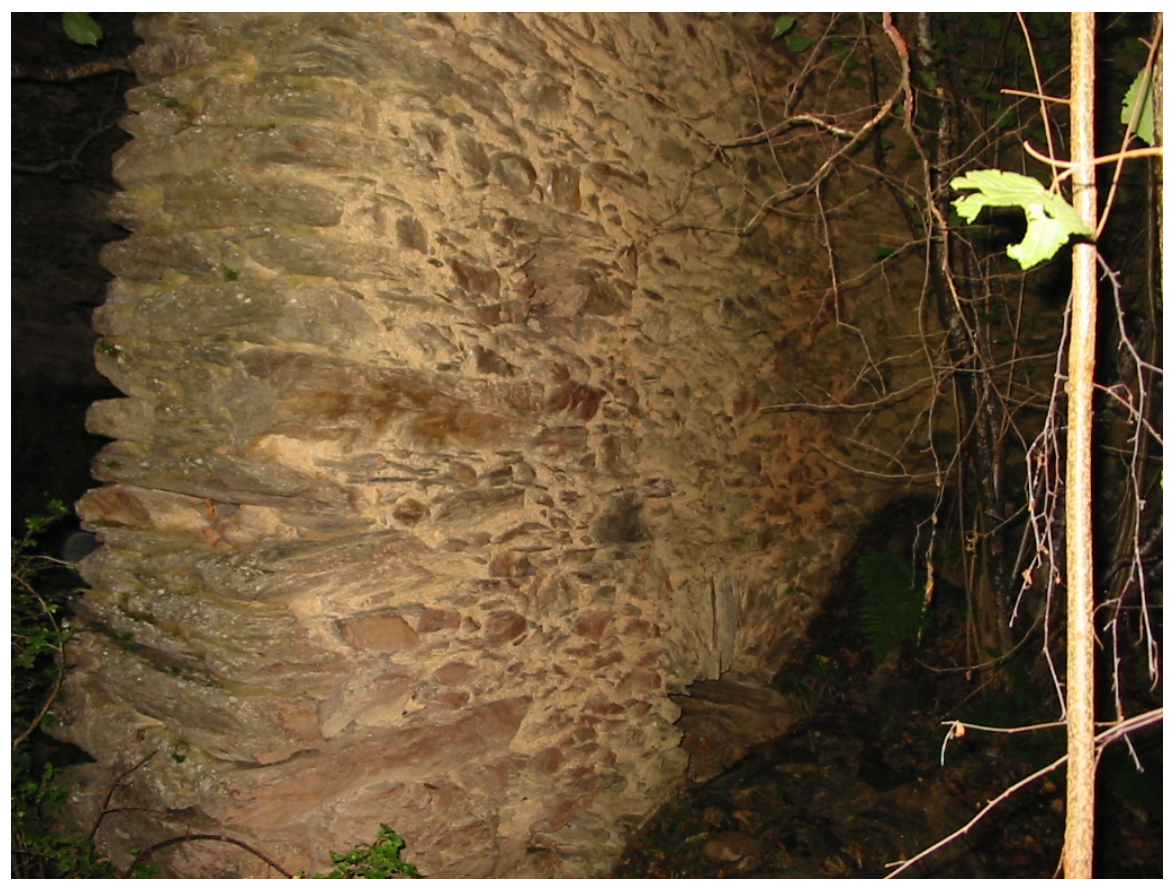

Fotografia 3. Restes de la Farga Catalana de Romadriu. Paret dels murs de l'edifici de la farga. Castellbó (Alt Urgell). Fotografia del maig del 2002 


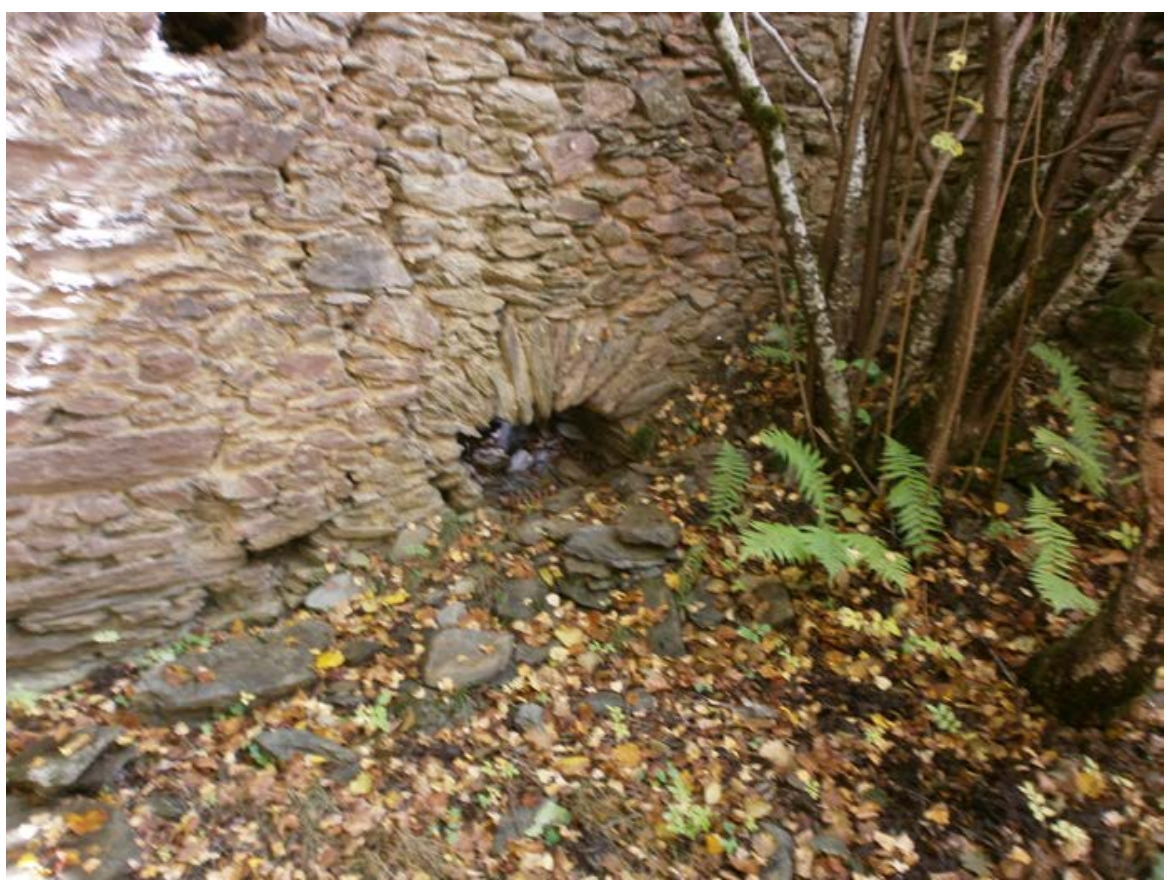

Fotografia 4. Restes de la Farga Catalana de Romadriu. Boca de sortida de l'aigua. Octubre del 2013

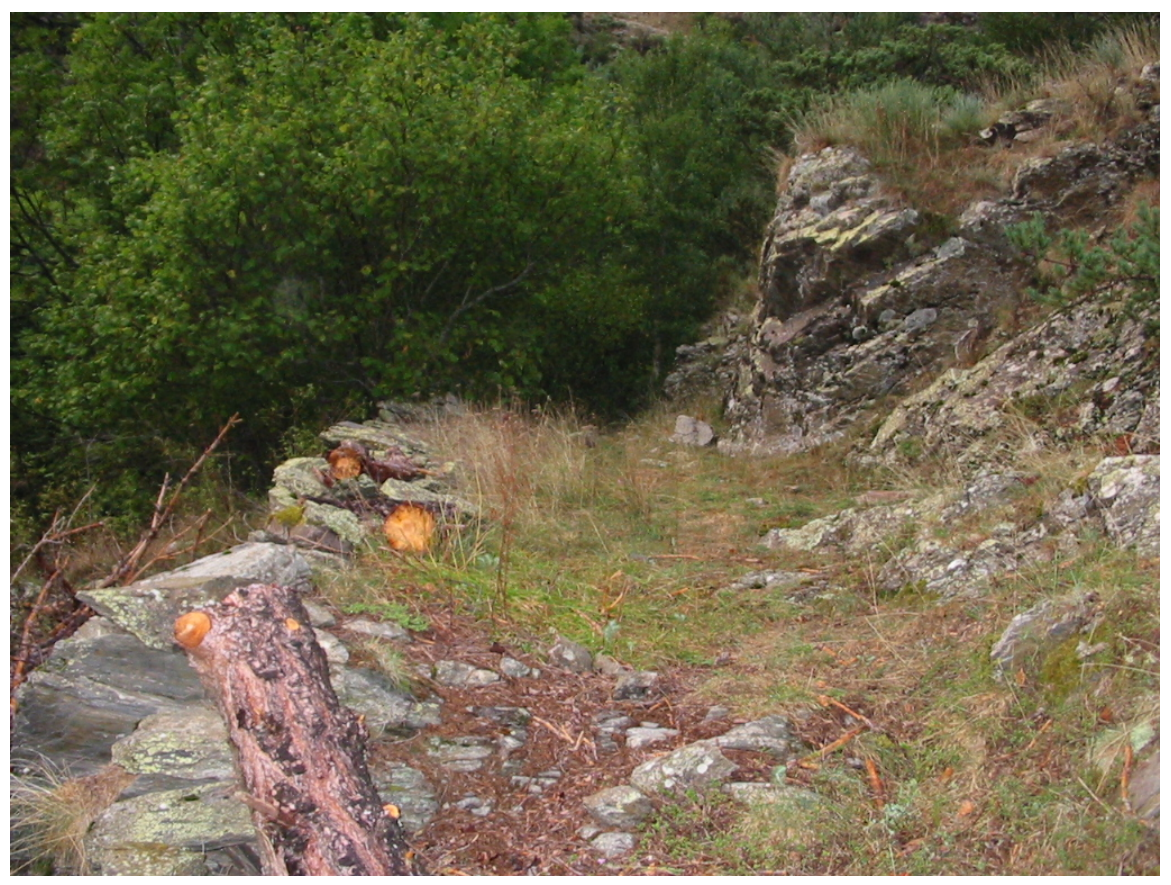

Fotografia 5. Restes de la Farga Catalana de Romadriu. Canalet reblert de sediments. Castellbó (alt Urgell). Fotografia del maig del 2002 


\subsection{Parada 5. CARRETERA A LES PISTES D’ESQUí DE PORT - AINÉ, (Montenartró, terme municipal de Llavorsí, comarca del Pallars Sobirà). (Full 215).}

Des de la parada anterior, ens caldrà retornar cap a la població de Montenartró. Després, ens caldrà retornar cap a Roni, des d'on anirem cap a les pistes d'esquí de I Orri i Port-Ainé. Així, ens caldrà arribar quasi fins a les instal-lacions de Port-Ainé. Però poc abans de fer-ho es trobarà un camí per l'esquerra, el qual ens conduirà cap a Sant Joan de I'Erm. Nosaltres, continuarem breument cap a Port - Ainé, fent una fillola. A uns 500 metres del trencall, farem una nova aturada. Així, des de la parada anterior, haurem recorregut uns $8 \mathrm{Km}$.

En aquest recorregut es van trobant exclusivament els nivells esquistosos de l'Ordovicià (i del Cambro - Ordovicià). Així, ens trobem situats dintre dels Apilaments Antiformes de la Zona Axial Pirinenca. Cal recordar que hem entrat en aquesta zona, poc després de sobrepassar la població de Rialp de Noguera.

En arribar a l'indret de l'aturada es fa present, per sobre de la carretera una important esllavissada, en la que es pot veure una gran tertera (fotografia 6).

Alhora, es veu clarament de que es tracta d'un terrenys enormement inestable, veient-se innumerables esquerdes a la carretera, així com algunes tendències a l'esfondrament. (fotografia 7).

En conjunt, es tracta d'una zona amb un evident i greu risc geològic, el qual es manifesta molt sovint.

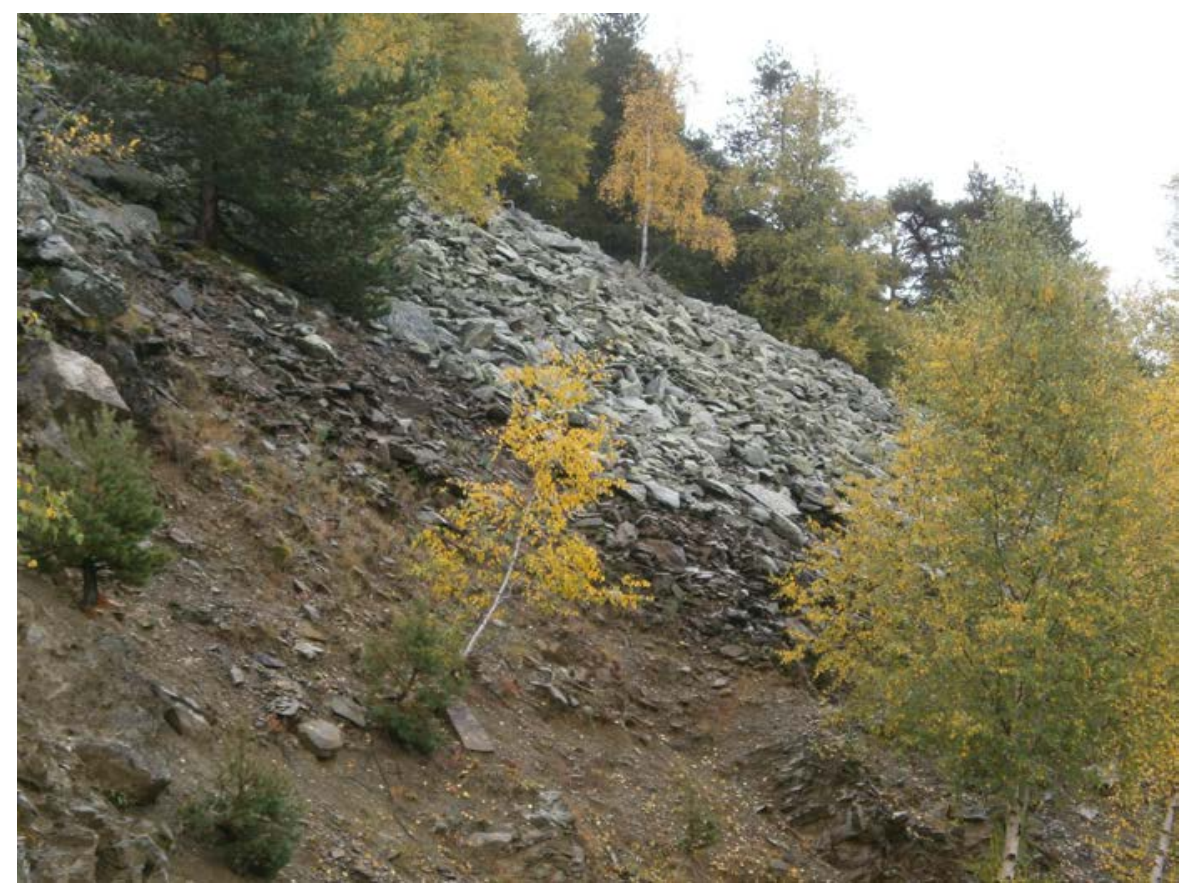

Fotografia 6. Un aspecte de la tertera sobre la carretera de Roni a Port - Ainé. Octubre 2013 


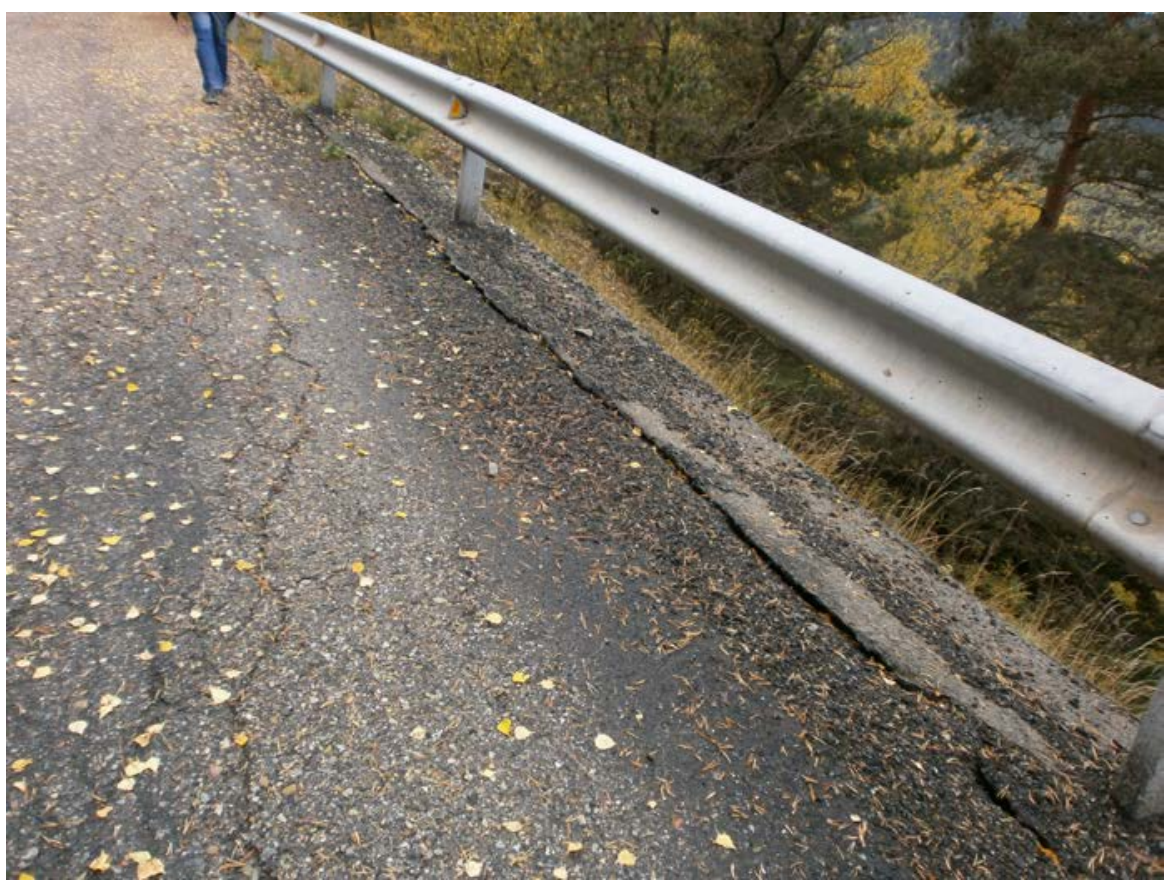

Fotografia 7. Un aspecte de les esquerdes de la carretera de Roni a Port - Ainé. Octubre 2013

Parada 6. MINA D'ANTIMONI DE MONTENARTÓ, (Montenartró, terme municipal de Llavorsí, comarca del Pallars Sobirà). (Full 215).

Des de la parada anterior, ens caldrà retornar cap a la cruïlla del camí que ens conduirà cap a Sant Joan de l'Erm. Finalment, a uns 0 ' $5 \mathrm{Km}$ de recorregut per aquest camí, es troben les mines. En arribar a aquest indret, ens caldrà fer la present aturada, després de recórrer uns $1 \mathrm{Km}$ de la parada anterior.

En aquest recorregut es van trobant exclusivament els nivells esquistosos de l'Ordovicià que ja hem esmentat a les aturades anteriors. Així, ens trobem situats dintre dels Apilaments Antiformes de la Zona Axial Pirinenca.

En aquest indret hi ha una mineralització filoniana, encaixada entre els esquistos de I'Ordovicià. Els filons tenen direccions NE-SW, i són gairebé verticalitats. La mineralització és de caràcter antimonífer, i els minerals primaris presents són: BOULANGERITA. DADSONITA, PLAGIONITA i ROBINSONITA. Per alteració d'aquests s'han format: CERVANTINITA, ESTIBICONITA, BINDHEIMITA i PIROMORFITA. Finalment, cal dir que es troben també altres minerals com: PIRITA, GOETHITA (limonita), CALCITA i QUARS. Possiblement hi hagi més minerals, ja que tenim noticia de la presencia de mineralitzacions de mercuri que no hem arribat mai a trobar. Aquest indret, pot considerar-se com un important PIM (Punt d'Interès Mineralògic). En efecte, alguns dels minerals anteriorment esmentats, sols es troben en aquest indret, dintre de Catalunya. Aquest és el cas de la PLAGIONITA, de la ROBINSONITA i també de la BINDHEIMITA.

Finalment, cal dir que aquesta mineralització es va intentar explotar en diverses ocasions, a finals del segle passat i a principis del present, sense cap mena d'èxit. Avui, les explotacions mineres es troben enrunades. (fotografia 8). 


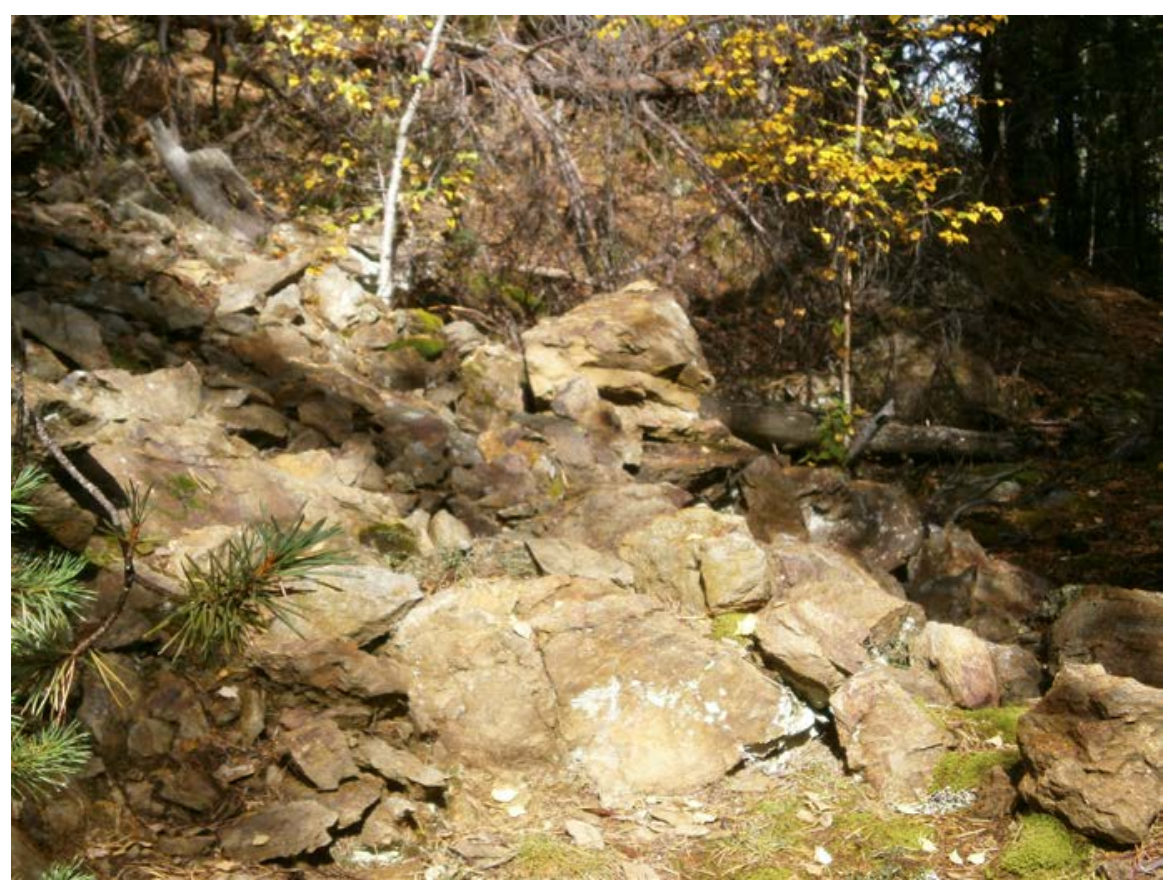

Fotografia 8. Escombreres de les Mines de Montenartró. Octubre del 2013

\subsection{Parada 7. SANT JOAN DE I'ERM VELL, (Sant Andreu, terme municipal de Castellbó - Montferrer, comarca de l’Alt Urgell). (Full 215).}

Des de la parada anterior, ens caldrà continuar cap a llevant, amb la intenció d'arribar fins a les immediacions de Sant Joan de I'Erm Vell. Així, haurem deixat la comarca del Pallars Sobirà i hem entrat a la de I'Alt Urgell, on ara ens trobem. En aquest indret farem una nova aturada, a uns $4 \mathrm{Km}$ de l'anterior. Aquí hi ha les restes de l'antic Sant Joan de l'Erm.

En aquest recorregut, haurem trobat exclusivament afloraments dels esquistos i de les quarsites de I'Ordovicià. Aquests materials es situen dintre dels Apilaments Antiformes de la Zona Axial Pirinenca.

Aquests materials acabats d'esmentar, son els que es troben a l'indret on realitzem la present aturada. Per d'altra banda, des d'aquest indret es pot fer una bona observació de la vall del Riu de santa Magdalena (o Riu de Romadriu), que baixa des de les Bordes de Conflent. (fotografia 9).

En aquest indret, hi ha unes interessants explicacions relatives a Sant Joan de I'Erm, i a la seva història.. 


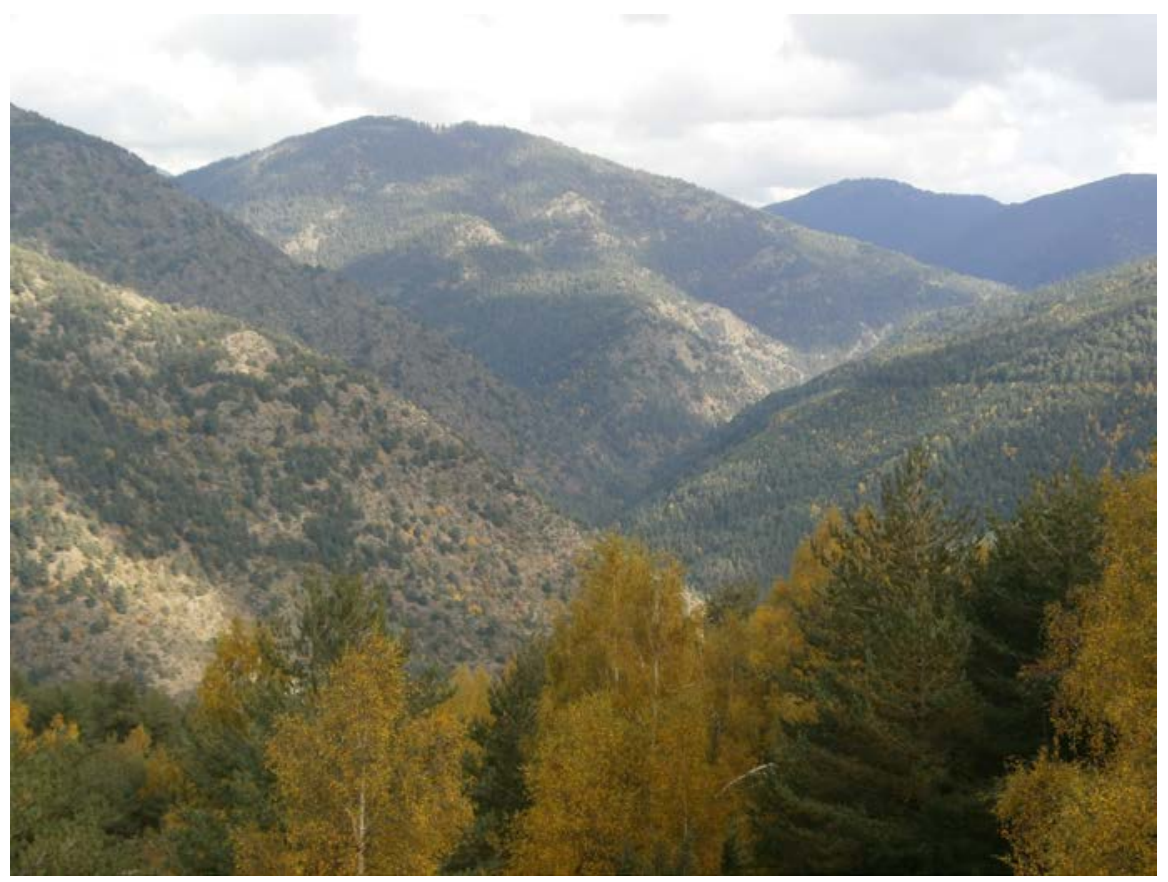

Fotografia 9. La Vall del Riu de santa Magdalena, des de Sant Joan de l’Erm Vell. Octubre del 2013

\subsection{Parada 8 - CONDICIONAL. SANT JOAN DE I'ERM NOU, (Sant Andreu, terme municipal de Castellbó - Montferrer, comarca de l’Alt Urgell). (Full 215).}

Des de la parada anterior, si s'escau, ens caldrà continuar cap a llevant, amb la intenció d'arribar fins a les immediacions de Sant Joan de I'Erm Nou, on ara ens trobem. En aquest indret farem una nova aturada, a uns $5 \mathrm{Km}$ de l'anterior. Aquí hi ha les restes de

Com al recorregut anterior, en aquest tram, haurem trobat exclusivament afloraments dels esquistos i de les quarsites de l'Ordovicià. Aquests materials es situen dintre dels Apilaments Antiformes de la Zona Axial Pirinenca, per on estem situats a les darreres aturades d'aquest itinerari.

Com a l'aturada anterior, aquests materials acabats d'esmentar, son els que es troben a I'indret on realitzem la present aturada.

En aquest indret finalitza el recorregut de l’itinerari. 


\section{Bibliografia}

GUIMERÀ, J. et altri (1992).- Geologia (II), Història Natural dels Països Catalans, Vol. 2, 547 pag. Enciclopèdia Catalana, S.A. Barcelona.

MATA-PERELLÓ, J.M. (1991).- Els Minerals de Catalunya. Arxius de la Secció de Ciències de I'Institut d'estudis Catalans, vol.47, 545 pàgines. Barcelona.

MATA-PERELLÓ, J.M. (1995a).- Itinerari Geològico-Mineralògic pel Pallars Jussà i pel Pallars Sobirà: des de Puimanyons a Sort. Inèdit, 13 pàgines. Barcelona.

MATA-PERELLÓ, J.M. (1995b).- Itinerari Geològico-Mineralògic pel Pallars Sobirà i per l’Alt Urgell: des de Gerri de la Sal a Sort i a Castellàs. Selecció d'itineraris, it. 14. pp. 131-138. Manresa.

MATA-PERELLÓ, J.M. (1996).- Circuït-itinerari de recerca geològica i mineralògica per l'Alt Urgell i pel Pallars Sobirà: des de la Palanca de Noves al Coll de Cantó i a la Palanca de Noves. Inèdit, 16 pag. Manresa.

MATA-PERELLÓ, J.M. (1998).- Recerca Geològica i Mineralògica per les comarques del Pallars Jussà i pel Pallars Sobirà: des del Congost d’Erinyà a la Plana de Mont-rós, i des Gerri de la Sal al Coll de Cantó, revista Algeps, nº 98, 14 pag. Manresa.

MATA-PERELLÓ, J.M. (2002).- Recerca geològica i mineralògica per la comarca del Pallars Sobirà: des del Gerri de la Sal i Montcortés a Sort i a Esterri d’Àneu. Inèdit. 12 pàgines. Manresa.

MATA-PERELLÓ, J.M. (2009a).- Recerca geològica i mineralògica per la comarca del Pallars Sobirà: des del Gerri de la Sal a Sort i a Esterri d’Àneu. . Inèdit. 10 pàgines. Manresa.

MATA-PERELLÓ, J.M. (2009b).- Recorregut de recerca geològic i mineralògica per les terres dels dos Pallars: des de la Pobla de Segur cap a Collegats, Gerri de la Sal, Estac i a Sort. 10 pàgines. Manresa.

MATA-PERELLÓ, J.M. (2009c).- Recorregut de recerca mineralògica i geològica a través de les per comarques del Pallars Sobirà i de l'Alt Urgell: des d'Alins, a Ferrera i a les Bordes de Conflent. Inèdit. 9 pàgines. Manresa.

MATA-PERELLÓ, J.M. (2012).- Recerca geològica i mineralògica per la comarca del Pallars Sobirà: des del Gerri de la sal a Sort i a Llavorsí. Inèdit. 8 pàgines. Manresa.

MATA-PERELLÓ, J.M i SANZ BALAGUÉ, J. (1993).- Guia de Identificación de Minerales, Edit Parcir. 215 pàgines. Manresa.

RIBA ARDERIU, O. et altri (1976).- Geografia Física dels Països Catalans. Edit Ketres. Barcelona.

SGC (1990).- Mapa Geològic de Catalunya a escala 1:250.000, Servei Geològic de Catalunya (Institut Cartogràfic de Catalunya). Barcelona. 